\title{
Evaluation cottonseed vigor through computer image analysis of the seedlings ${ }^{1}$
}

\author{
Plínio Duarte Corrêa², Silvio Moure Cicero², Haynna Fernandes Abud ${ }^{3 *}$
}

\begin{abstract}
The evaluation of seed vigor through image analysis has been gaining space in quality-control programs due to its easy use, objectivity, and speed. This study aimed at assessing the computer image analysis of seedling as a method for evaluate cottonseed (SVIS ${ }^{\circledR}$ ), and compare it with tests traditionally employed for the same purpose. The experiments used cottonseeds of the cultivar FM975WS. First germination count, accelerated aging, low-temperature germination, emergence in sand and emergence-in sand speed index, seedling emergence in the field, and computer analysis were used to evaluate the seed vigor. The results showed that performing the computer image analysis with the software SVIS $^{\circledR}$ is a viable alternative to assess the vigor of cottonseeds.
\end{abstract}

Index terms: Gossypium hirsutum L., physiological potential, computer image, seedlings.

\section{Avaliação do vigor de sementes de algodão através de análise computadorizada de imagens de plântulas}

\begin{abstract}
RESUMO - A avaliação do vigor de sementes por meio da análise de imagens vem ganhando espaço devido à sua praticidade, objetividade e rapidez. Assim, o objetivo desta pesquisa foi avaliar a o método de análise computadorizada de imagens de plântulas $\left(\right.$ SVIS $\left.^{\circledR}\right)$ e sua relação com os testes tradicionais utilizados para avaliação do vigor de sementes de algodão da cultivar FM975WS. Para avaliar o vigor das sementes, foram utilizados os testes de primeira contagem de germinação, envelhecimento acelerado, germinação a baixa temperatura, emergência e índice de velocidade de emergência de plântulas em areia, emergência de plântulas no campo e análise computadorizada de plântulas. Concluiu-se que o software Seed Vigor Imaging System (SVIS ${ }^{\circledR}$ ), como técnica de análise computadorizada de imagens de plântulas, é uma alternativa para avaliar o vigor de sementes de algodão, havendo similaridade com outros testes tradicionalmente utilizados com a mesma finalidade.
\end{abstract}

Termos para indexação: Gossypium hirsutum L., potencial fisiológico, análise computadorizada, plântulas.

\section{Introduction}

Seed quality is defined as the sum of physical, physiological, genetical, and sanitary attributes, which can guarantee the maximum production of a crop, as long as they are associated with adequate external factors. Thus, obtaining high-quality seeds is essential to integrate the various production steps (Marcos-Filho, 2015a), and viability and vigor tests are ways to estimate such potential.

The germination test is traditionally used to assess the physiological quality of seeds. However, since the procedure conditions are controlled, it does not always

${ }^{1}$ Submitted on 05/24/2018. Accepted for publication on 09/27/2018. ${ }^{2}$ Departamento de Produção Vegetal, USP/ESALQ, Caixa Postal 9, 13418-900 - Piracicaba, SP, Brasil. reflect the real potential of the lot in the field. On account of that, vigor tests become a useful complement (Demir et al., 2008; Marcos-Filho, 2015b).

Conventional tests for evaluating the vigor of seeds are generally time-consuming and subjective at some level (Pinto et al., 2015). So, the most up-to-date techniques aim at assuring the standardization, precision, objectivity, and reliability of the results (Marcos-Filho et al., 2006). In that context, computer analyses of images of seedlings have risen as a promising alternative to provide accurate information on the physiological potential of seeds (Chiquito et al., 2012).

The software Seed Vigor Imaging System $\left(\right.$ SVIS $\left.^{\circledR}\right)$
${ }^{3}$ Departamento de Fitotecnia, Universidade Federal do Ceará. Avenida Humberto Monte s/n., 60440-900 - Fortaleza, CE, Brasil.

*Corresponding author <hfabud@gmail.com> 
for image processing, developed at Ohio State University, effortlessly delivers fast results. This technology provides vigor and uniformity indices, as well as seedling measurements (Hoffmaster et al., 2005). Also, the time taken to obtain specific vigor parameters, such as seedling length, is considerably shorter than that necessary when the evaluation is conducted manually.

Differences in vigor are supposed to be assessed on the date specified for conducting the first germination count (Gomes Junior et al., 2014). Nevertheless, in many species, such evaluation is performed before the due time. So, since the software performance is sensitive to such differences, it is a better alternative for spotting them. Other advantages of this system include the elimination of subjectivity posed by manual analysis, the increase of reliability of the results as comparative tools, and the possibility of saving the images for further studies (Gomes Junior et al., 2009).

After performing some adaptations, Hoffmaster et al. (2003) successfully employed the software $\mathrm{SVIS}^{\circledR}$ to investigate the vigor of soybean seeds. Alvarenga and Marcos-Filho (2014), in their turn, were able to identify differences in cottonseed vigor during storage. The efficiency of this system was also proved for several other species, including peanuts (Marchi et al., 2011; Barbosa et al., 2016), super sweet corn (Alvarenga et al., 2012), wheat (Silva et al., 2012), beans (Gomes Junior et al., 2014), soybeans (Wendt et al., 2014), sunflower (Rocha et al., 2015), and sorghum (Javorski et al., 2018). When evaluating lots of sweet corn after their physiological conditioning, Gomes Junior et al. (2009) observed a relation with other typically used tests. The software was also used successfully for gauging the length of corn seedling roots (Dias et al., 2015).

On that account, this work aimed at analyzing the method of computer image analysis of seedlings, by utilizing the software Seed Vigor Imaging System $\left(\right.$ SVIS $\left.^{\circledR}\right)$. Then, the results were used to establish a relationship between this technique and other usual tests for assessing the vigor of cottonseeds.

\section{Material and Methods}

The study was carried out in the laboratories of Seed Analysis and Image Analysis, both belonging to the Department of Plant Production, at Escola Superior de Agricultura "Luiz de Queiroz" (ESALQ) of Universidade de São Paulo (USP), based in Piracicaba, Brazilian state of São Paulo (SP).

Cottonseeds from ten lots of the cultivar FM975WS were used. The seeds were provided by the company Bayer CropScience, which had already treated them with the insecticide $\mathrm{CropStar}^{\circledR}$ (imidacloprid and thiodicarb) and the fungicides Dynasty ${ }^{\circledR}$ (azoxystrobin, metalaxyl-M, and fludoxonil), Monceren $250 \mathrm{SC}^{\circledR}$ (Pencycuron), and Baytan
$\mathrm{SC}^{\circledR}$ (triadimenol), at the usual commercial dosages for cottonseeds. A polymer $\left(\right.$ Peridiam $^{\circledR}$ ) and a drying powder (Talkum Gloss $^{\circledR}$ ) were also applied for coating the seeds.

The seeds were packed in paper Kraft packaging and stored for six months in a controlled environment, with a temperature of $10 \pm 1{ }^{\circ} \mathrm{C}$ and air relative humidity of $30 \%$. The evaluations were conducted in two temporally separated sets of trials: one performed right after the seeds arrived at the laboratory, and another carried out by the end of the storage period.

Water content was determined in both groups of experiment and after the accelerated aging test. To do so, samples of about $4 \mathrm{~g}$ from each lot were placed in an oven at $105 \pm 3{ }^{\circ} \mathrm{C}$ for $24 \mathrm{~h}$, as recommended by Regras para Análise de Sementes (Brasil, 2009). The experiment was performed with two replications, and the results were expressed as percentage (wet basis).

For the computer image analysis of seedlings, seeds were arranged on the upper-third of a germitest paper. A total of 200 seeds was used, which were divided into 10 replications of 20 seeds, distributed in two rows. The paper rolls were kept inside a germinator at a constant temperature of $25^{\circ} \mathrm{C}$, and the evaluation was conducted on the third day after sowing. Then, all seedlings and ungerminated seeds were placed on a blackcolored paper sheet, which acted as a contrasting background to make seedling characteristics more prominent for capturing the images. Next, the seedlings were scanned with an HP Scanjet $2410^{\circledR}$ device, operated by the software Photosmart ${ }^{\circledR}$, with a 100-dpi resolution. This scanner had been placed inside an aluminum box (dimensioned $60 \times 50 \times 12 \mathrm{~cm}$ ) in an inverted orientation. The images produced were appraised with the software Seed Vigor Imaging System (SVIS ${ }^{\circledR}$ ), thus obtaining the mean values of the indices of vigor and growth uniformity of each lot (Hoffmaster et al., 2005). The data were converted from pixels to centimeters to measure seedling length.

For seedling analysis, the software settings were adjusted considering a combination of growth parameters $(70 \%$ contribution) and seedling uniformity ( $30 \%$ contribution).

Simultaneously to the computer analysis of seedlings, determinations of water content, germination and vigor were also conducted. In all these tests, four replications of 50 seeds per lots were used.

Germination and first germination count: they were carried out on a germitest paper roll, moistened at the proportion of $2.5 \mathrm{~mL}$ of distilled water per $1 \mathrm{~g}$ of substrate, and then kept in a germinator at a constant temperature of $25^{\circ} \mathrm{C}$. The first germination count was performed on the fourth day, and the final count on the twelfth day after sowing, thus taking into account the percentage of normal seedlings, as suggested by Brasil (2009).

Low-temperature germination: the test was conducted 
as aforementioned, but at $18{ }^{\circ} \mathrm{C}$ instead. The evaluation was performed seven days after sowing, considering as normal those seedlings with the root-hypocotyl axis equal to or bigger than four centimeters (Baalbaki et al., 2009). The results were expressed as percentage of normal seedlings.

Accelerated aging: plastic boxes (dimensioned $11.0 \mathrm{x}$ $11.0 \times 3.0 \mathrm{~cm}$ ) were employed as individual compartments (mini-chambers). They had an internal prop supporting a metallic screen, on top of which the seeds were spread in a single layer. The bottom of the boxes, below the screen, was filled with 40 $\mathrm{mL}$ of water. Then, they were covered and placed inside a BOD chamber at $41{ }^{\circ} \mathrm{C}$ for $48 \mathrm{~h}$ (Miguel et al., 2001). After this period, the germination test was performed and assessed on the fourth day after sowing, as previously described.

Seedling emergence in sand and emergence speed index: the seeds were arranged on a $6-\mathrm{cm}$ layer of medium-textured sand, placed inside plastic boxes (dimensioned $32 \times 28 \times$ $10 \mathrm{~cm}$ ). After sowing, they were covered with $3 \mathrm{~cm}$ of sand moistened with $60 \%$ the retention capacity of the substrate, and the boxes were kept in a greenhouse. The evaluations were conducted daily, by registering the number of emerged seedlings in each lot until the fourteenth day after sowing, when the mean percentage of seedling emerged of each lot was determined. For obtaining the seedling emergence speed index, the equation proposed by Maguire (1962) was used.

Seedling emergence in the field: seeds of each lot were planted at approximately $3 \mathrm{~cm}$ depth, in $0.5 \mathrm{~m}$ spaced $2 \mathrm{~m}$ length lines, and then covered with dirt. The evaluation was carried out on the fourteenth day after sowing, when the number of emerged seedlings was counted. The criterion used was the complete expansion of the cotyledonary leaves. The results were expressed as the percentage of seedlings emerged per lot (Nakagawa, 1999).

Germination, traditional vigor tests, and computer image analysis of seedlings $\left(\right.$ SVIS $\left.^{\circledR}\right)$ were performed according to a completely randomized design; whereas the seedling emergence in the field adopted a randomized block design. The resulting data were subjected to analysis of variance, and the means were compared by the Scott-Knott test at a $5 \%$ probability level. The data were statistically appraised considering each set of trials, by using the software SISVAR ${ }^{\circledR}$.

\section{Results and Discussion}

The seeds showed an initial water content between 6.7 and $7.4 \%$, and after the accelerated aging process these values raised to 19.1 to $21.9 \%$. Therefore, the water content probably did not affect seed behavior during the tests, once the variation among lots was little significant, meaning that the seeds absorbed water at similar speed.

Table 1 presents the results of all tests conducted during the first trials. According to the germination outcomes, the lots were statistically sorted into four categories. Lots 2, 3, 4, and 7 produced the highest percentages of normal seedlings, whereas lot 9 showed the lowest values. Once the standard required for cottonseed commercialization is at least $75 \%$ germination, lots 9 and 11 are not suitable.

Table 1. Results obtained in the first period of trials for the parameters water content (WC), germination percentage (G), first germination count (FGC), water content after accelerated aging (WC AA), accelerated aging (AA), low-temperature germination (LTG), seedling emergence in sand (SES), seedling emergence in the field (SEF), emergence-in-sand speed index (ESI), seedling length (SL), vigor index (VI), and seedling growth uniformity index (UI) of all lots. The evaluations were performed three days after germination.

\begin{tabular}{ccccccccccccc}
\hline Lots & WC $^{1}$ & $\mathrm{G}^{1}$ & FGC $^{1}$ & WC AA $^{1}$ & AA $^{1}$ & LTG $^{1}$ & SES $^{1}$ & SEF $^{1}$ & ESI & SL $^{2}$ & VI & UI \\
\hline L2 & 7.0 & $92 \mathrm{a}^{*}$ & $87 \mathrm{a}$ & 19.5 & $88 \mathrm{a}$ & $81 \mathrm{a}$ & $94 \mathrm{a}$ & $91 \mathrm{a}$ & $8.77 \mathrm{a}$ & $6.8 \mathrm{~b}$ & $751 \mathrm{c}$ & $886 \mathrm{a}$ \\
L3 & 7.4 & $87 \mathrm{a}$ & $85 \mathrm{a}$ & 21.4 & $91 \mathrm{a}$ & $82 \mathrm{a}$ & $94 \mathrm{a}$ & $91 \mathrm{a}$ & $8.83 \mathrm{a}$ & $6.8 \mathrm{~b}$ & $753 \mathrm{c}$ & $898 \mathrm{a}$ \\
L4 & 7.3 & $89 \mathrm{a}$ & $89 \mathrm{a}$ & 20.1 & $85 \mathrm{a}$ & $86 \mathrm{a}$ & $94 \mathrm{a}$ & $91 \mathrm{a}$ & $8.69 \mathrm{a}$ & $6.4 \mathrm{~b}$ & $837 \mathrm{~b}$ & $893 \mathrm{a}$ \\
L6 & 6.9 & $85 \mathrm{~b}$ & $73 \mathrm{~b}$ & 20.2 & $80 \mathrm{a}$ & $84 \mathrm{a}$ & $97 \mathrm{a}$ & $90 \mathrm{a}$ & $9.13 \mathrm{a}$ & $6.4 \mathrm{~b}$ & $854 \mathrm{~b}$ & $884 \mathrm{a}$ \\
L7 & 7.1 & $92 \mathrm{a}$ & $84 \mathrm{a}$ & 21.0 & $85 \mathrm{a}$ & $88 \mathrm{a}$ & $95 \mathrm{a}$ & $89 \mathrm{a}$ & $8.89 \mathrm{a}$ & $7.3 \mathrm{a}$ & $919 \mathrm{a}$ & $901 \mathrm{a}$ \\
L8 & 6.7 & $81 \mathrm{~b}$ & $77 \mathrm{~b}$ & 20.1 & $42 \mathrm{c}$ & $61 \mathrm{~b}$ & $90 \mathrm{a}$ & $86 \mathrm{~b}$ & $8.38 \mathrm{~b}$ & $4.7 \mathrm{c}$ & $697 \mathrm{~d}$ & $873 \mathrm{~b}$ \\
L9 & 6.9 & $63 \mathrm{~d}$ & $54 \mathrm{~d}$ & 21.3 & $41 \mathrm{c}$ & $46 \mathrm{c}$ & $88 \mathrm{a}$ & $84 \mathrm{~b}$ & $8.16 \mathrm{~b}$ & $4.1 \mathrm{~d}$ & $727 \mathrm{~d}$ & $858 \mathrm{~b}$ \\
L10 & 7.0 & $81 \mathrm{~b}$ & $75 \mathrm{~b}$ & 19.1 & $55 \mathrm{~b}$ & $43 \mathrm{c}$ & $92 \mathrm{a}$ & $84 \mathrm{~b}$ & $8.46 \mathrm{~b}$ & $4.3 \mathrm{~d}$ & $661 \mathrm{~d}$ & $859 \mathrm{~b}$ \\
L11 & 6.7 & $72 \mathrm{c}$ & $65 \mathrm{c}$ & 20.6 & $47 \mathrm{c}$ & $37 \mathrm{c}$ & $90 \mathrm{a}$ & $81 \mathrm{~b}$ & $8.08 \mathrm{~b}$ & $4.7 \mathrm{c}$ & $693 \mathrm{~d}$ & $881 \mathrm{a}$ \\
L13 & 7.0 & $78 \mathrm{~b}$ & $76 \mathrm{~b}$ & 21.9 & $42 \mathrm{c}$ & $41 \mathrm{c}$ & $92 \mathrm{a}$ & $84 \mathrm{~b}$ & $8.40 \mathrm{~b}$ & $4.9 \mathrm{c}$ & $727 \mathrm{c}$ & $877 \mathrm{~b}$ \\
\hline CV (\%) & - & 6.56 & 7.34 & - & 8.39 & 10.08 & 3.84 & 6.29 & 4.36 & 9.89 & 6.07 & 3.64 \\
\hline
\end{tabular}

${ }^{1}$ Mean values in percentage; ${ }^{2}$ mean values in centimeters; ${ }^{*}$ means followed by the same letter, in the column, do not differ, according to the Scott-Knott test ( $\mathrm{p} \leq 0.05$ ). 
As for the first germination count, a significant difference was noticed between the lots, similarly to what was observed in the germination test (Table 1). The lots with the highest percentages also showed the best performances in an environment with favorable controlled conditions, which made it difficult to separate them into levels of vigor. The first count is based on the principle that the higher the germination percentage by the fourth day after sowing, the more vigorous the lot. It is a fast, yet relevant test, once seedling uniformity and emergence speed are the most important features within the current concept of seed vigor (Marcos-Filho, 2015a).

Concerning the accelerated aging test, lots $2,3,4,6$, and 7 (Table 1) had the best performances, while lots $8,9,11$, and 13 delivered the worst results. This test is highly efficient in sorting cottonseed lots, as also verified by Alvarenga and Marcos-Filho (2014).

In the germination test at low temperature $\left(18{ }^{\circ} \mathrm{C}\right)$, lots 2, 3, 4, 6, and 7 showed the highest percentages of normal seedlings. Lot 8 was intermediary, and lots $9,10,11$, and 13 presented the lowest values (Table 1). Thus, these results are in agreement with those of the first germination count and accelerated aging tests.

No significant differences were observed in the test of seedling emergence in sand (Table 1). Differently, the seedling emergence speed index detected a significant difference among the lots, following the same pattern as the aforementioned tests: lots 2, 3, 4, 6, and 7 exhibited the highest vigor; while lots $8,9,10,11$, and 13 showed the lowest (Table 1).

Seedling emergence in the field, likewise the results of the emergence speed index, sorted the lots into two performance groups. The first one, including lots $2,3,4,6$, and 7 , showed the highest percentages of emerged seedlings; and the other, including the lots $8,9,10,11$, and 13, registered the lowest values (Table 1).

A similarity was observed among the groups sorted out by the vigor tests. In general, lots 2, 3, 4, 6, and 7 had the best performances, even though lot 6 got intermediary results in the germination and first germination count tests. Lots 8, 9, 10, 11, and 13 showed some differences among the vigor trials used, but their outcomes were always inferior to the others (Table 1).

It is worth remarking that, despite the relation observed among the vigor tests employed in this study, each one of them analyzes different aspects related to seed vigor. So, not always are the lots arranged in the same qualitative order (Marcos-Filho et al., 2009). In fact, as the number of tests and lots increase, the more difficult their interpretation becomes.

Table 1 also contains the findings of the computer analysis of seedlings. Regarding their length, lot 7 exhibited the best outcome, followed by lots 2, 3, 4, and 6. On the other hand, seedlings of these lots were longer than those of lots 8,11 , and
13; while lots 9 and 10 produced the shortest ones. As for the vigor index, lot 7 also had the best performance. Lots 2, 3, 4, 6 , and 13 showed intermediate values, and the lowest indices were observed in lots $8,9,10$, and 11 (Table 1).

The seedling growth uniformity index (Table 1) made it possible to distinguish two groups. Besides, seedling emergence in the field and emergence speed index also showed similar behavior to the uniformity index. Such an index is essential to assess the vigor of seeds because it evaluates the capacity of seedlings of developing evenly (Marcos-Filho et al., 2009). This quality is highly desirable for obtaining uniform stands in the field, so the maximum productive potential of crops can be reached.

Table 2 presents the results for the second trials. In this case, the water content of the seeds ranged from 6.2 to $6.8 \%$ and, after the accelerated aging test, these values raised to 17.7 to $20,1 \%$. So, as in the first trials, there was little variation in the water content of the lots (less than $2.5 \%$ in both cases), which implies that the results are accurate.

The germination test statistically separated the lots into three groups: lots 2, 3, 4, 6, and 7 presented the highest percentages of normal seedlings; lots $8,9,10$, and 13 displayed an intermediate behavior; and lot 11 showed the lowest value (Table 4). Once considered that the standard for cottonseed commercialization requires minimum germination of $75 \%$, only lots $2,3,4,6$, and 7 are suitable for this purpose.

Lots showed significant differences in all traditional vigor test performed. In general, the outcomes were similar to those obtained in the first trials (Table 1).

The results of the first germination count essentially produced the same stratification scheme as of the germination analysis. The only exceptions were lots 9 and 13, which presented an intermediate percentage of normal seedlings in the latter test, and a low value in the former (Table 2).

The accelerated aging test sorted the lots into four groups of vigor. Lots 2, 3, and 7 got the highest percentages of normal seedlings, followed by lots 4 and 6 . In their turn, lots $8,9,10,11$, and 13 had the lowest performance rates, with germination after accelerated aging lower than $40 \%$ (Table 2).

As for the low-temperature germination, lots 2, 3, and 4 had the best performance, while lot 8 had the worst. The other ones placed intermediary (Table 2).

The emergence-in-sand test identified only two levels. The best-performing group included lots 2, 3, 4, 6, 7, and 8; while the remaining were considered as low vigored. The experiments of seedling emergence in the field and emergence speed index resulted in a classification similar to the one produced from the seedling emergence in sand, except for the fact that lot 8 was included in the low-performing group (Table 2). 
Table 2. Results obtained in the second period of trials for the parameters water content (WC), germination percentage (G), first germination count (FGC), water content after accelerated aging (WC AA), accelerated aging (AA), low-temperature germination (LTG), seedling emergence in sand (SES), seedling emergence in the field (SEF), emergence-in-sand speed index (ESI), seedling length (SL), vigor index (VI), and seedling growth uniformity index (UI) of all lots. The evaluations were performed three days after germination.

\begin{tabular}{cccccccccccccc}
\hline Lots & WC $^{1}$ & $\mathrm{G}^{1}$ & FGC $^{1}$ & WC AA $^{1}$ & AA $^{1}$ & LTG $^{1}$ & SES $^{1}$ & SEF $^{1}$ & ESI $^{\text {SL }^{2}}$ & VI $^{\text {UI }}$ \\
\hline L2 & 6.5 & $84 \mathrm{a}^{*}$ & $71 \mathrm{a}$ & 18.0 & $79 \mathrm{a}$ & $77 \mathrm{a}$ & $88 \mathrm{a}$ & $64 \mathrm{a}$ & $6.65 \mathrm{a}$ & $6.24 \mathrm{a}$ & $727 \mathrm{a}$ & $860 \mathrm{a}$ \\
L3 & 6.5 & $84 \mathrm{a}$ & $74 \mathrm{a}$ & 19.1 & $81 \mathrm{a}$ & $78 \mathrm{a}$ & $86 \mathrm{a}$ & $65 \mathrm{a}$ & $6.19 \mathrm{a}$ & $6.35 \mathrm{a}$ & $732 \mathrm{a}$ & $879 \mathrm{a}$ \\
L4 & 6.2 & $86 \mathrm{a}$ & $81 \mathrm{a}$ & 19.9 & $66 \mathrm{~b}$ & $77 \mathrm{a}$ & $87 \mathrm{a}$ & $64 \mathrm{a}$ & $6.36 \mathrm{a}$ & $6.26 \mathrm{a}$ & $734 \mathrm{a}$ & $870 \mathrm{a}$ \\
L6 & 6.6 & $87 \mathrm{a}$ & $69 \mathrm{a}$ & 18.6 & $72 \mathrm{~b}$ & $67 \mathrm{~b}$ & $88 \mathrm{a}$ & $64 \mathrm{a}$ & $6.38 \mathrm{a}$ & $5.75 \mathrm{~b}$ & $698 \mathrm{~b}$ & $858 \mathrm{a}$ \\
L7 & 6.3 & $89 \mathrm{a}$ & $73 \mathrm{a}$ & 19.9 & $80 \mathrm{a}$ & $65 \mathrm{~b}$ & $91 \mathrm{a}$ & $56 \mathrm{a}$ & $6.41 \mathrm{a}$ & $6.18 \mathrm{a}$ & $732 \mathrm{a}$ & $849 \mathrm{a}$ \\
L8 & 6.2 & $68 \mathrm{~b}$ & $57 \mathrm{~b}$ & 20.1 & $37 \mathrm{c}$ & $15 \mathrm{~d}$ & $85 \mathrm{a}$ & $35 \mathrm{~b}$ & $5.63 \mathrm{~b}$ & $4.63 \mathrm{c}$ & $597 \mathrm{c}$ & $867 \mathrm{a}$ \\
L9 & 6.8 & $72 \mathrm{~b}$ & $46 \mathrm{c}$ & 17.7 & $39 \mathrm{c}$ & $34 \mathrm{c}$ & $73 \mathrm{~b}$ & $40 \mathrm{~b}$ & $4.99 \mathrm{~b}$ & $4.59 \mathrm{c}$ & $600 \mathrm{c}$ & $859 \mathrm{a}$ \\
L10 & 6.7 & $73 \mathrm{~b}$ & $56 \mathrm{~b}$ & 18.4 & $35 \mathrm{c}$ & $43 \mathrm{c}$ & $79 \mathrm{~b}$ & $37 \mathrm{~b}$ & $5.40 \mathrm{~b}$ & $4.26 \mathrm{c}$ & $574 \mathrm{c}$ & $861 \mathrm{a}$ \\
L11 & 6.6 & $60 \mathrm{c}$ & $45 \mathrm{c}$ & 18.8 & $25 \mathrm{~d}$ & $37 \mathrm{c}$ & $76 \mathrm{~b}$ & $35 \mathrm{~b}$ & $5.70 \mathrm{~b}$ & $4.38 \mathrm{c}$ & $584 \mathrm{c}$ & $858 \mathrm{a}$ \\
L13 & 6.5 & $70 \mathrm{~b}$ & $48 \mathrm{c}$ & 19.3 & $30 \mathrm{~d}$ & $33 \mathrm{c}$ & $78 \mathrm{~b}$ & $36 \mathrm{~b}$ & $5.39 \mathrm{~b}$ & $4.43 \mathrm{c}$ & $580 \mathrm{c}$ & $873 \mathrm{a}$ \\
\hline CV (\%) & - & 8.41 & 12.44 & - & 9.07 & 13.57 & 8.75 & 20.44 & 12.12 & 9.63 & 5.21 & 4.43 \\
\hline
\end{tabular}

${ }^{1}$ Mean values in percentage; ${ }^{2}$ mean values in centimeters; ${ }^{*}$ means followed by the same letter, in the column, do not differ, according to the Scott-Knott test ( $\left.\mathrm{p} \leq 0.05\right)$.

In the first trials, seedling emergence in sand did not sort the lots. However, in the second moment, lots 9, 10, 11, and 13 showed low performance. For the variables seedling emergence in the field and emergence speed index, the same lot classification was obtained in both sets of trials.

Table 2 also contains the findings from the computer image analysis of the seedlings. According to them, the lots could be classified in three groups of vigor, based on seedling length and vigor index: lots 2, 3, 4, and 7 had the best performance, lot 6 placed intermediary, and the remaining showed the worst results.

The uniformity index in this set of evaluations showed similar behavior among all lots (Table 2). The same outcome was not observed during the first analyses (Table 1).

It was possible to infer that, in the second set of trials, the computer image analysis of cotton seedlings appraised the vigor of seeds as effectively as other tests traditionally used for the same purpose. Marcos-Filho (2015b) also observed that the indices of vigor, uniformity and seedling length are compatible with the conventional tests employed to analyze the vigor of seed lots.

Computer image analysis is a useful method for quality control programs. In this sense, using the software SVIS ${ }^{\circledR}$ reduces both the time consumed and the subjectivity of the seedling length analysis. Also, it provides data on the vigor index and uniformity of seedlings, which might help to obtain more consistent conclusions regarding seed lots.

\section{Conclusions}

For analyzing computer images of seedlings, the software Seed Vigor Imaging System (SVIS ${ }^{\circledR}$ ) is an alternative tool to assess the vigor of cottonseeds. Also, there are similarities between this method and others that are traditionally used for the same purpose.

\section{Acknowledgments}

To Coordenação de Aperfeiçoamento de Pessoal de Nível Superior (CAPES) for granting a scholarship for the first author.

\section{References}

ALVARENGA, R.O.; MARCOS-FILHO, J.; GOMES JUNIOR, F.G. Avaliação do vigor de sementes de milho superdoce por meio da análise computadorizada de imagens de plântulas. Revista Brasileira de Sementes, v.34, n.3, p.488-494, 2012. http://www.scielo.br/pdf/rbs/v34n3/17.pdf

ALVARENGA, R.O.; MARCOS-FILHO, J. Avaliação do vigor de sementes armazenadas de algodão, incluindo a análise computadorizada de imagens (SVIS $\left.{ }^{\circ}\right)$. Journal of Seed Science, v.36, n.2, p.222-230, 2014. http://www.scielo.br/pdf/jss/v36n2/v36n2a11.pdf

BAALBAKI, R.Z.; ELIAS, S.; MARCOS-FILHO, J.; McDONALD, M.B. Seed vigor testing handbook. Ithaca: AOSA, 2009.

BARBOSA, R.M.; VIEIRA, B.G.T.L.; GOMES JUNIOR, F. G.; VIEIRA, R.D. Image analysis and peanut seeds performance during the production process. Cientifica. v.44, n.3, p.412-420, 2016. http:// cientifica.org.br/index.php/cientifica/article/view/765/520 
BRASIL. Ministério da Agricultura, Pecuária e Abastecimento. Regras para análise de sementes. Ministério da Agricultura, Pecuária e Abastecimento. Secretaria de Defesa Agropecuária. Brasília, DF: MAPA/ACS, 2009. 395p. http://www.agricultura.gov.br/arq_editor/ file/2946_regras_analise_sementes.pdf

CHIQUITO, A.A.; GOMES-JUNIOR, F.G.; MARCOS-FILHO, J. Assessment of physiological potential of cucumber seeds using the software Seedling Vigor Imaging System (SVIS). Revista Brasileira de Sementes, v.34, p.255-263, 2012. http://www.scielo.br/pdf/rbs/ v34n2/10.pdf

DEMIR, I.; MAVI, K.; KENANOGLU, B.; MATTHEWS, S. Prediction of germination and vigour in naturally aged commercially available seed lots of cabbage (Brassica oleracea var. capitata) using the bulk conductivity method. Seed Science and Technology, v.36, n.3, p.509-523, 2008. https:/www.researchgate.net/ publication/233518699_Prediction_of_germination_and_vigour_ in_naturally_aged_commercially_available_seed_lots_of_cabbage Brassica_oleracea_var_capitata_using_the_bulk_conductivity_method

DIAS, M.A.N.; MONDO, V.H.V.; CICERO, S.M.; GONÇALVES, N.R.; SILVA, C.A.T. Vigor tests association as an alternative for precise and efficient assessment of maize seed quality. Revista Caatinga, v.28, n.3, p.93-99, 2015. http://www.scielo.br/scielo. php?script=sci_arttext\&pid=S1983-21252015000300093

GOMES JUNIOR, F.G.; MONDO, V.H.V.; CICERO, S.M.; McDONALD, M.B.; BENNETT, M.A. Evaluation of priming effects on sweet corn seeds by SVIS. Seed Technology, v.31, n.1, p.95-100, 2009. http://www.jstor.org/stable/23433510?seq=1\#page_ scan_tab_contents

GOMES JUNIOR, F.G.; CHAMMA, H.M.C.P.; CÍCERO, S.M. Automated image analysis of seedling for vigor evaluation of common bean seeds Acta Scientiarum. Agronomy, v.36, n.2, p.195200, 2014. http://www.scielo.br/pdf/asagr/v36n2/v36n2a08.pdf

HOFFMASTER, A.L.; FUJIMURA, K.; MCDONALD, M.B.; BENNET, M.A. An automated system for vigour testing threeday-old soybean seedlings. Seed Science and Technology, v.31, p.701-713, 2003. http://www.ingentaconnect.com/content/ista/ sst/2003/00000031/00000003/art00019

HOFFMASTER, A.L.; XU, L.; FUJIMURA, K.; McDONALD, M.B.; BENNET, M.A.; EVANS, A.F. The Ohio State University seed vigor imaging system (SVIS) for soybean and corn seedlings. Seed Technology, v.27, n.1, p.7-26, 2005. http://europepmc.org/ search/?page=1\&query=AUTH:\%22Hoffmaster + AF $\% 22$

JAVORSKI, M ; CASTAN, D.O.C. ; SILVA, S.S. ; GOMES JUNIOR, F. G.; CICERO, S.M. Image analysis to evaluate the physiological potential and morphology of pearl millet seeds. Journal of Seed Science, v. 40, p. 127-134, 2018. http://dx.doi.org/10.18512/19806477/rbms.v16n2p310-318

MAGUIRE, J.D. Speed of germination-aid selection and evaluation for seedling emergence and vigor. Crop Science, v.2, n.2, p.176-177, 1962. http://dx.doi.org/10.2135/cropsci1962.0011183X000200020033x
MARCHI, J.L.; CICERO, S.M.; GOMES-JUNIOR, G.G. Utilização da análise computadorizada na avaliação do potencial fisiológico de sementes de amendoim tratadas com fungicidas e inseticidas. Revista Brasileira de Sementes, v.33, n.4, p.562-662, 2011. www.scielo.br/ scielo.php?script $=$ sci_abstract\&pid=S0101-31222011000400007\&ln $\mathrm{g}=\mathrm{en} \& \mathrm{tlng}=\mathrm{pt}$

MARCOS-FILHO, J. Fisiologia de sementes de plantas cultivadas. Londrina: ABRATES, 2015a.

MARCOS-FILHO, J. Seed vigor testing: an overview of the past, present and future perspective. Scientia Agricola, v.72, n.4, p.365-374, 2015b. http://www.scielo.br/pdf/sa/v72n4/0103-9016-sa-72-4-0363.pdf

MARCOS-FILHO, J.; BENNETTI, M.A.; McDONALD, M.B.; EVANS, A.F.; GRASSBAUGH, E.M. Assessment of melon seed vigour by an automated computer imaging system compared to traditional procedures. Seed Science and Technology, v.34, n.2, p.485497, 2006. https://www.researchgate.net/publication/233677333_ Assessment_of_melon_seed_vigour_by_an_automated_computer_ imaging_system_compared_to_traditional_procedures

MARCOS-FILHO, J.; KIKUTI, A.L.P.; LIMA, L.B. Métodos para avaliação do vigor de sementes de soja, incluindo análise computadorizada de imagens. Revista Brasileira de Sementes, v.31, n.1, p.102-112, 2009. http://www.scielo.br/pdf/rbs/v31n1/a12v31n1.pdf

MIGUEL, M.H.; CARVALHO, M.V.; BECKERT, O. P.; MARCOSFILHO, J. Teste de frio para avaliação do potencial fisiológico de sementes de algodão. Scientia Agricola, v.58, n.4, p.741-746, 2001. http://www.scielo.br/scielo.php?script=sci_abstract\&pid=S0103$90162001000400015 \& \operatorname{lng}=\mathrm{e} \& \mathrm{t} \operatorname{lng}=\mathrm{pt}$

NAKAGAWA, J. Testes de vigor baseados no desempenho das plântulas. In: KRZYZANOWISKI, F.C.; VIEIRA, R.D.; FRANÇANETO, J.B. (Ed.). Vigor de sementes: conceitos e testes. ABRATES, 1999. p.2.1-2.24.

PINTO, C.A.G.; CARVALHO, M.L.M.; ANDRADE, D.B.; LEITE, E.R.; CHALFOUNS, I. Image analysis in the evaluation of the physiological potential of maize seeds. Revista Ciência Agronomica, v.46, n.2, p.319-328, 2015. http://www.scielo.br/scielo. php?script $=$ sci_arttext\&pid=S1806-66902015000200319

ROCHA, C.R.M.; SILVA, V.N.; CICERO, S.M. Avaliação do vigor de sementes de girassol por meio de análise de imagens de plântulas. Ciência Rural, v.45, n.6, p.970-976, 2015. http:// www.scielo.br/scielo.php? script $=$ sci_abstract\&pid $=$ S0103$84782015000600970 \& \operatorname{lng}=\mathrm{es} \& \operatorname{tlng}=\mathrm{pt}$

SILVA, V.N.; GOMES JUNIOR, F.G.; CICERO, S.M. Computerized imaging analysis of seedlings for assessment of physiological potential of wheat seeds. Revista Brasileira de Sementes, v.34, n.4, p.589-596, 2012. http://www.scielo.br/scielo.php?script=sci arttext\&pid=S0101-31222012000400009

WENDT, L.; GOMES-JUNIOR, F.G.; ZORATO, M.F.; MOREIRA, G.C. Avaliação do potencial fisiológico de sementes de soja por meio de imagens. Pesquisa Agropecuária Tropical, v.44, n.3, p.280-286, 2014. http://www.scielo.br/pdf/pat/v44n3/a11v44n3.pdf 